The Walnut Mansion 
Other publications by Miljenko Jergović previously translated into English

Sarajevo Marlboro

Ruta Tannenbaum

Mama Leone 


\section{The Walnut Mansion}

MILJENKO JERGOVIĆ

TRANSLATED BY STEPHEN M. DICKEY, WITH JANJA PAVETIĆ-DICKEY

YALE UNIVERSITY PRESS — NEW HAVEN \& LONDON 
The Margellos World Republic of Letters is dedicated to making literary works from around the globe available in English through translation. It brings to the English-speaking world the work of leading poets, novelists, essayists, philosophers, and playwrights from Europe, Latin America, Africa, Asia, and the Middle East to stimulate international discourse and creative exchange.

Copyright $\odot$ Miljenko Jergović 2003.

English translation copyright @ 2015 by Stephen M. Dickey and Janja Pavetić-Dickey.

First published as Dvori od oraha by Durieux, Zagreb, 2003.

All rights reserved.

This book may not be reproduced, in whole or in part, including illustrations, in any form (beyond that copying permitted by Sections 107 and 108 of the U.S. Copyright Law and except by reviewers for the public press), without written permission from the publishers.

Yale University Press books may be purchased in quantity for educational, business, or promotional use. For information, please e-mail sales.press@yale.edu (U.S. office) or sales@yaleup.co.uk (U.K. office).

Set in Electra and Nobel types by Tseng Information Systems, Inc.

Printed in the United States of America.

ISBN: 978-0-300-17927-9 (cloth; alk. paper)

Library of Congress Control Number: 2015937574

A catalogue record for this book is available from the British Library.

This paper meets the requirements of ANSI/NISO Z39.48-1992 (Permanence of Paper).

10987654321 